\title{
Monitoring Spatial and Temporal Scales of Shoreline Changes in Lahou-Kpanda (Southern Ivory Coast) Using Landsat Data Series (TM, ETM+ and OLI)
}

\begin{abstract}
Shoreline changes are crucial for assessing human-ecosystem interactions in coastal environments. They are a valuable tool for determining the environmental costs of socioeconomic growth along coasts. In this research, we present an assessment of shoreline changes along the eastern coast of Lahou-Kpanda of the Ivory Coast during the period from 1980 to 2020 by applying Digital Shoreline Analysis System method using Landsat Data Series. The measurement of the shoreline dynamics of the Lahou-Kpanda coastline is mainly described in three parts: the west straight cordon, the dynamics at the mouth and the east straight cordon. The findings show a drastic reduction in natural shorelines. The greatest transition occurred along the mouth segment of the coast, where the average erosive velocity approaches 90 meters each year and the average distance has decreased by around 2 kilometers. The Ivory Coast lost more than $40 \%$ of its biological shorelines between 1980 and 2020, according to this report, a worrying development because these are regions that were once biologically abundant and highly rich. In general, human operations on the Ivory Coast's shorelines have never had such an impact. The effects of these changes on habitats, as well as the vulnerability of new shoreline investments to increased human activity and sea-level rise, must be measured.
\end{abstract}

Keywords: shoreline change, remote sensing, DSAS, Landsat, Lahou-Kpanda

Received: 9 May 2021; accepted: 28 October 2021

(C) 2022 Authors. This is an open access publication, which can be used, distributed and reproduced in any medium according to the Creative Commons CC-BY 4.0 License.

1 Laboratory of Demography and Spatial Dynamics, University Alassane Ouattara-Bouaké, Ivory Coast, email: ruthovirginia@gmail.com, (D) https://orcid.org/0000-0002-4901-9920

2 Laboratory of Applied Geology, Geomatics and Environment, Faculty of Sciences Ben M'sik, Morocco, email: bachri.imane@gmail.com, (1) https://orcid.org/0000-0001-6146-5213

3 Laboratory of Demography and Spatial Dynamics, University Alassane Ouattara-Bouaké, Ivory Coast, email: henrijoel1958@gmail.com, (D) https://orcid.org/0000-0001-5413-5179

4 Laboratory of Demography and Spatial Dynamics, University Alassane Ouattara-Bouaké, Ivory Coast, email: harryfashion@outlook.fr, (1) https://orcid.org/0000-0002-8808-4426 


\section{Introduction}

A coastal zone is a transition area between the land and water. It represents a very important natural and economic resource [1-3], despite the fact that it is constantly changing. In addition, this microcosm is a highly complex environment in which erosion phenomena, and therefore the retreat or advance of the coastline, are influenced by a wide range of meteorological, geographical, biological, and anthropogenic influences [4-6]. Monitoring the coastal zone is important in a variety of applications, including sustainable development, cartography, and environmental protection [7-9].

As with most coastal areas around the world, the coastal zones of West Africa have been marked in recent decades by a natural process that shapes the shores. The coastal zone of Ivory Coast, part of the West African coastal zone, is subject to marine erosion (Fig. 1). In fact, two-thirds of the Ivorian coastline is destabilized by coastal erosion, and this will continue to increase given the amplification of socio-economic pressure on the coast and global projections relating to the impacts of climate change, suggesting an increase in sea level rises and leading to the reinforcement of erosion processes on the low-lying coasts [10]. In Grand-Lahou, the most important fishing sector, coastal erosion threatens Lahou-Kpanda, a fishing village, and is characterized by the destruction of infrastructure, tourist sites and habitats. Given the real danger that coastal erosion poses to this village, and given the need to prevent coastal risks in a context of climate change, it is essential to characterize the spatial and temporal evolution of the line on the coastline of Lahou-Kpanda (in the south of the Ivory Coast).
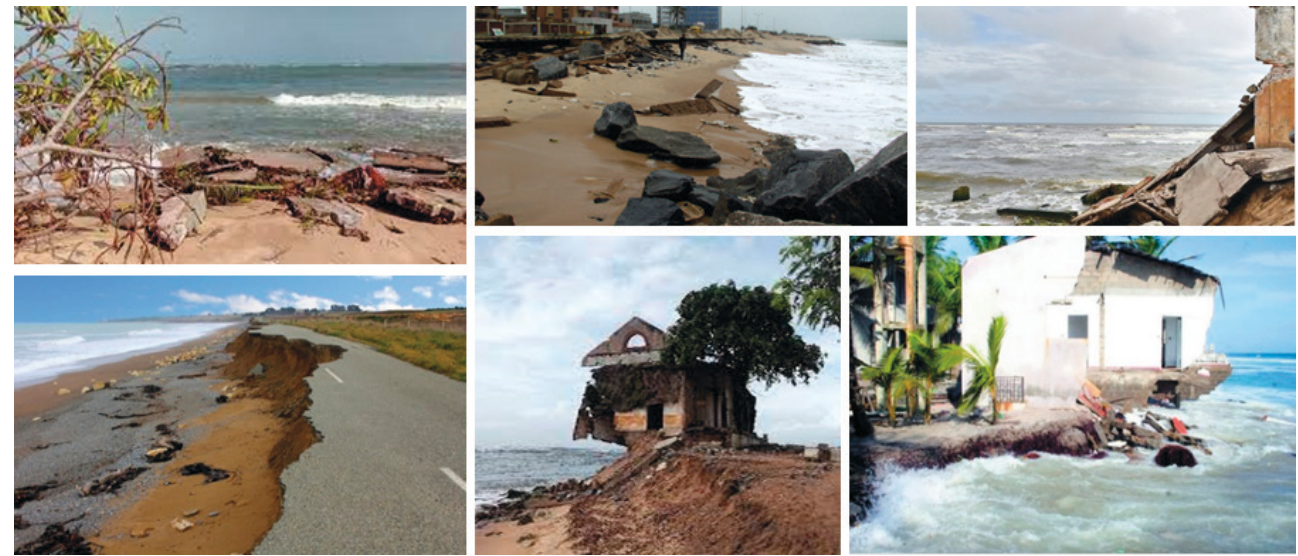

Fig. 1. Pictures of the eroding coastline of Ivory Coast

Remotely sensed data plays an important role in the identification, monitoring and delineation of coastline change at regional or global scales [11-14]. The availability of multi-band, multi-temporal and multi-sensor images and advances in digital 
treatment and analysis have allowed scientists to gather information on spatial and temporal changes and on the sensitivity of alterations due to natural and anthropogenic events. In this research, Landsat satellite data from 1980, 1987, 2000, 2015, 2017 and 2020 were used to examine the shoreline changes that have occurred during the past 40 years in the coastal area.

The study has the following specific research objectives (i) to examine the shoreline changes in shoreline along the coast over the past 30 years (1980 to 2020) and (ii) to explain the mechanism(s) that caused these changes. Aside from its local implications (Grand-Lahou, southern Ivory Coast), the current study could add to the literature and research domain more broadly in terms of shoreline change analysis at the local, international, and global levels. Also, it might be utilized for subsequent research, particularly in coastal dynamics and the management of shore erosion and vulnerability mitigation $[15,16]$. Using multi-temporal Landsat satellite images, the study explores shoreline alteration, coastal erosion, and accretion heterogeneity in a long-term scenario. The study's findings can be useful for erosion threat management in Grand-Lahou, which is one of Ivory Coast's most vulnerable coastal region, as well as a guide for future research and coastal hazard management at the local, international, and global levels.

\section{Study Area Description}

\subsection{Geographic Situation}

Lahou-Kpanda is a village in the Grand-Lahou commune in the Ivory Coast's south-west region. It is bordered by the Gulf of Guinea, at the mouth of the Bandaman River, and is situated between $5^{\circ} 07^{\prime} 37^{\prime \prime}$ and $5^{\circ} 08^{\prime} 12^{\prime \prime} \mathrm{N}$ and $4^{\circ} 59^{\prime} 01^{\prime \prime}$ and $5^{\circ} 08^{\prime} 12^{\prime \prime}$ W (Fig. 2b). The lagoons' (administrative) area includes Grand-Lahou. The geography of the area is characterized by thick woodland, with vast swaths of low-lying land and marshland. With temperatures ranging from 20 to $30^{\circ} \mathrm{C}$, the sub-equatorial atmosphere is hot and humid. There are two major seasons (dry and rainy) and two shorter seasons that are somewhat similar. The annual rainfall is $2000 \mathrm{~mm}$.

\subsection{Geological Context}

The Ivory Coast is split into two geological structures that are of unequal significance and separated chronologically [17-20]. In the one side, in the south, there is a late secondary to quaternary sedimentary basin that occupies $2.5 \%$ of the region and covers $30,000 \mathrm{~km}^{2}$. This basin stretches from Sassandra (in the west) to the Ghana frontier (in the east) (Fig. 2a).

This portion of the basin (onshore) is very narrow in the west, but it widens to 35 kilometers at the level of Abidjan level. A large fault, known as the "lagoon fault", 
runs through the basin from west to east, dividing it into two parts: To the north, the fault's formations are finer, made up of clays, clayey soils, and more or less ferruginous sandstones of "terminal continental" age [21, 22]. The outcropping rocks in the south are thicker, and they are dominated by quaternary deposits made up of white sands and continental clayey beaches, sandy cordons, sands, fluvio-lagunar argillites, and maritime sands. However, the remaining $97.5 \%$ is taken up by a Precambrian basement. The research area is a part of Ivory Coast's coastline, precisely Grand-Lahou.

a)
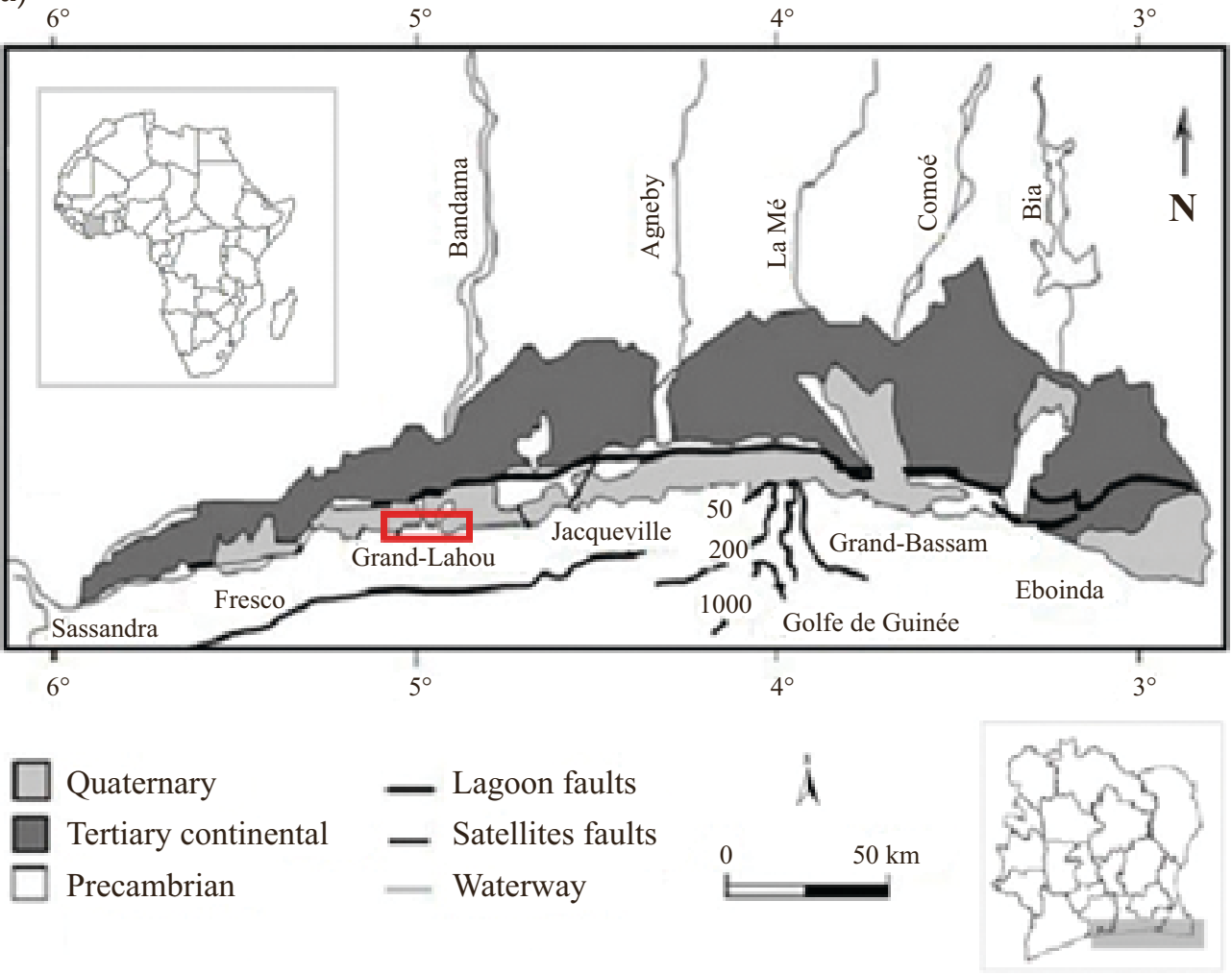

b)

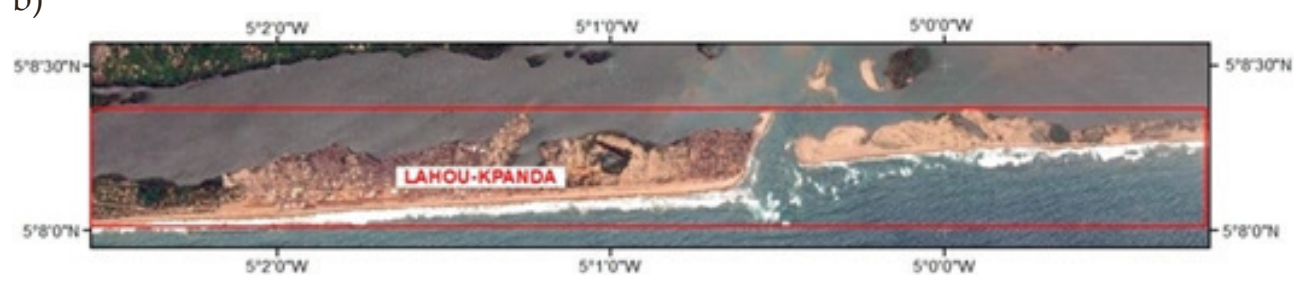

Fig. 2. Map of the Ivorian onshore sedimentary basin (a) and location of Lahou-Kpanda (b) Source: [23] (Fig. 2a) 


\section{Materials and Methods}

\subsection{Data Used}

Remote sensing data is a valuable tool for detecting coastline changes. It is crucial in the interpretation and mapping of data, since water absorbs infrared wavelengths and vegetation and soil reflect them strongly, multispectral images are an excellent combination for mapping the spatial distribution of land and water. Landsat satellite images represent the longest continuously acquired collection in the world of space-based earth remote sensing data. In this context, a series of Landsat images between 1980 and 2020 were used to determine of coastline changes in the study area, as presented in Table 1 . These multispectral images were obtained by the United States Geological Survey (USGS).

Table 1. Dataset of Landsat images used for coastline changes of the Ivory Coast

\begin{tabular}{|c|c|c|c|c||}
\hline Dates & Satellite/sensor & Path/Row & $\begin{array}{c}\text { Spatial resolution } \\
{[\mathrm{m}]}\end{array}$ & $\begin{array}{c}\text { Radiometric } \\
\text { resolution [bit] }\end{array}$ \\
\hline \hline $11 / 03 / 1980$ & Landsat TM & $196 / 056$ & $30 \times 30$ & 8 \\
\hline $10 / 04 / 1987$ & Landsat TM & $196 / 056$ & $30 \times 30$ & 8 \\
\hline $20 / 11 / 2000$ & Landsat ETM+ & $196 / 056$ & $30 \times 30$ & 12 \\
\hline $03 / 12 / 2015$ & Landsat OLI & $196 / 056$ & $30 \times 30$ & 12 \\
\hline $30 / 05 / 2017$ & Landsat OLI & $196 / 056$ & $30 \times 30$ & 12 \\
\hline $05 / 01 / 2020$ & Landsat OLI & $196 / 056$ & $30 \times 30$ & \\
\hline
\end{tabular}

\subsection{Methodology}

Landsat data series (TM, ETM+ and OLI) from 1980 to 2020 were used to track and discern shoreline changes, and have thus proven useful for studies relevant to coastal zone management [24-26]. The Landsat satellite images downloaded are in UTM projection, zone 30, and WGS 84 datum. A scheme was set up to analyze the shoreline change along the Lahou-Kpanda coastal strip, as shown in Figure 3.

After pre-processing (geometric correction, radiometric calibration, and atmospheric correction) of the images, shorelines were extracted by digitizing all satellite images of different time periods as shapefiles and used as input to the Digital Shoreline Analysis System (DSAS) tool. This is a tool for calculating the rate of change of the shoreline from a time series of multiple shoreline positions. It provides a robust suite of regression rates in a consistent and simply repeatable method so as to be run on large volumes of data collection at different scales [27-30]. Transects were developed using DSAS after the buffer was created with a margin of 15 meters to analyze 
the changes along the Lahou-Kpanda coast, and shoreline change statistics were determined in the form of Linear Regression Rate (LRR), Weighted Linear Regression, and End Point Rate (EPR). The LRR is calculated by fitting a least-squares regression line to all shoreline locations for a given transect. The uncertainty value is not taken into account when computing the shoreline change rate. The WLR technique is used to calculate the shoreline change rate. The approach for calculating shoreline rates of change is based on measured changes in coastline locations over time. The EPR is a straightforward technique that calculates change rates by dividing the distance between the oldest and youngest shorelines by the time interval between them.

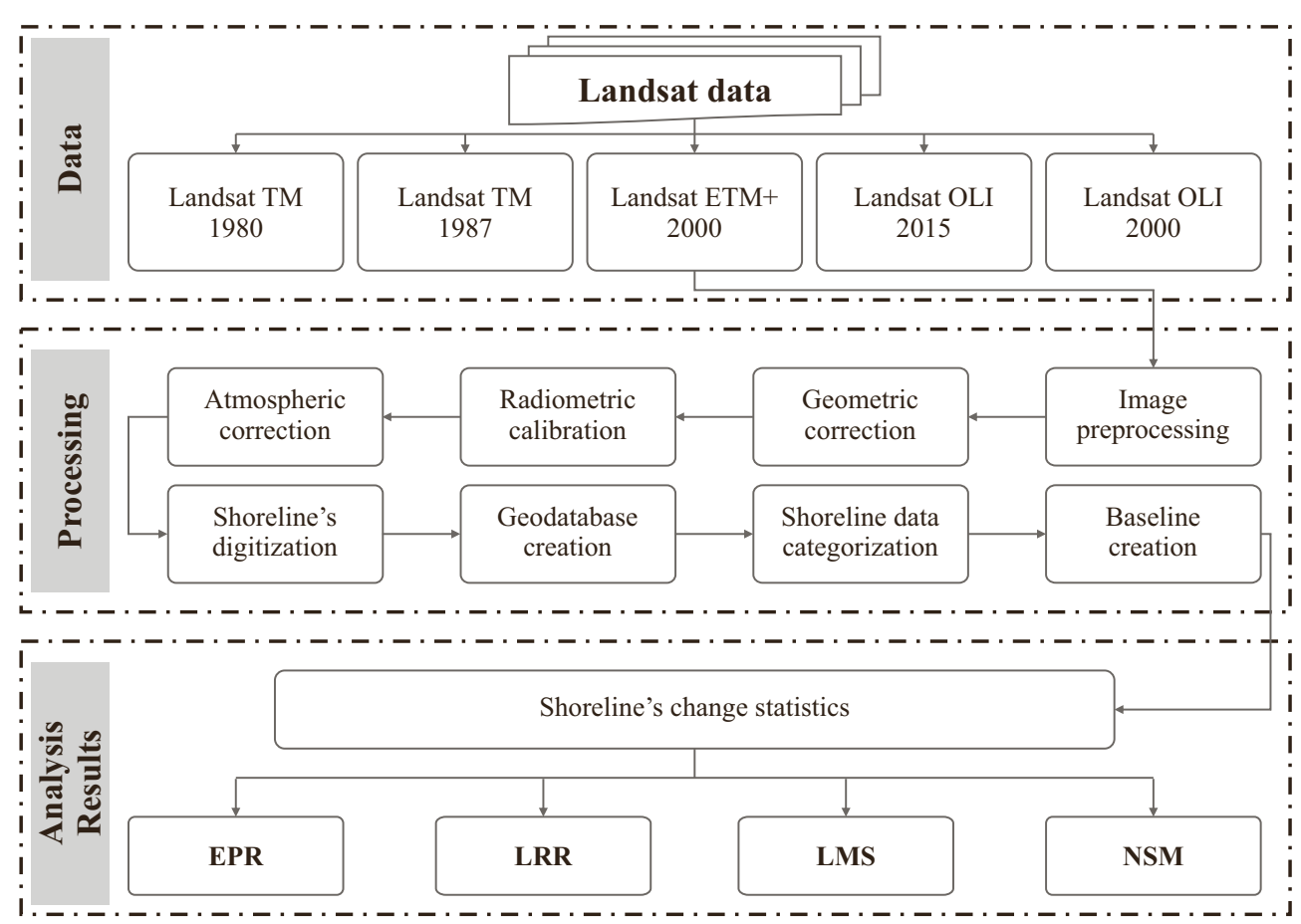

Fig. 3. Flowchart of the shoreline extraction process

\section{Results and Discussion}

\subsection{Morpho-dynamic Evolution of the Coastline of the Lahou-Kpanda Cordon}

The Lahou-Kpanda perimeter is composed of three trend parts (A, B and C). Part A (Fig. 4a) consists of all the straight zones of the perimeter's coastline. It is composed of the straight zone of the West Barrier and the straight zone of the East Barrier. It is an irregular zone because the coastline varies little over the period 1980-2020. 
The 1980-1987 coastline is perfectly prograded along the western barrier reef shoreline. However, its two variants overlap as it approaches the mouth and gradually leads to erosion. This evolution is certainly not the same on the eastern barrier beach. The coastline has two characteristics, but the priority is given to erosion. On the western barrier, the trend is the same and is repeated for the periods 1980-2000, 1980-2015, 1980-2017 and 1980-2020. From 1987 to 2000, the coasts are very often straddling, favoring either accretion or erosion zones. A fairly identical description for the 1987-2015, 1987-2017, and 1987-2020 periods. The 2000 and 2015 coastlines also straddle each other, but erosion is always observed near the mouth.

a)

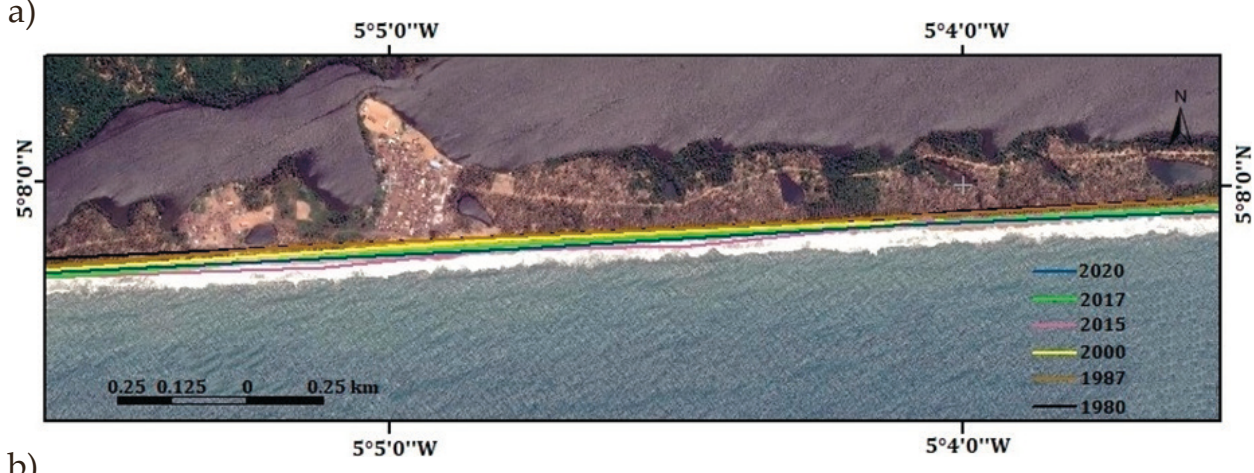

b)

5॰1'0"W

$5^{\circ} 0^{\prime} 0^{\prime \prime} \mathrm{W}$

$4^{\circ} 59^{\prime} 0^{\prime \prime} W$

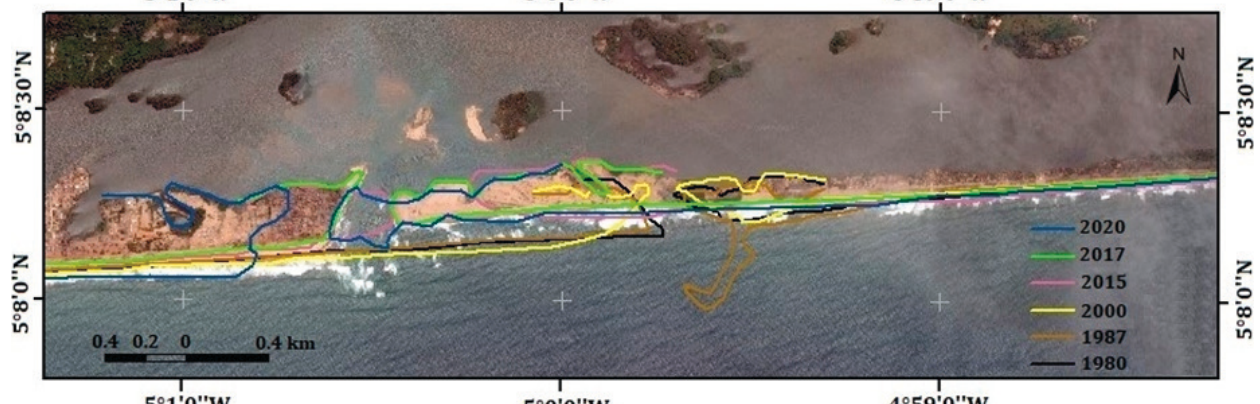

c)

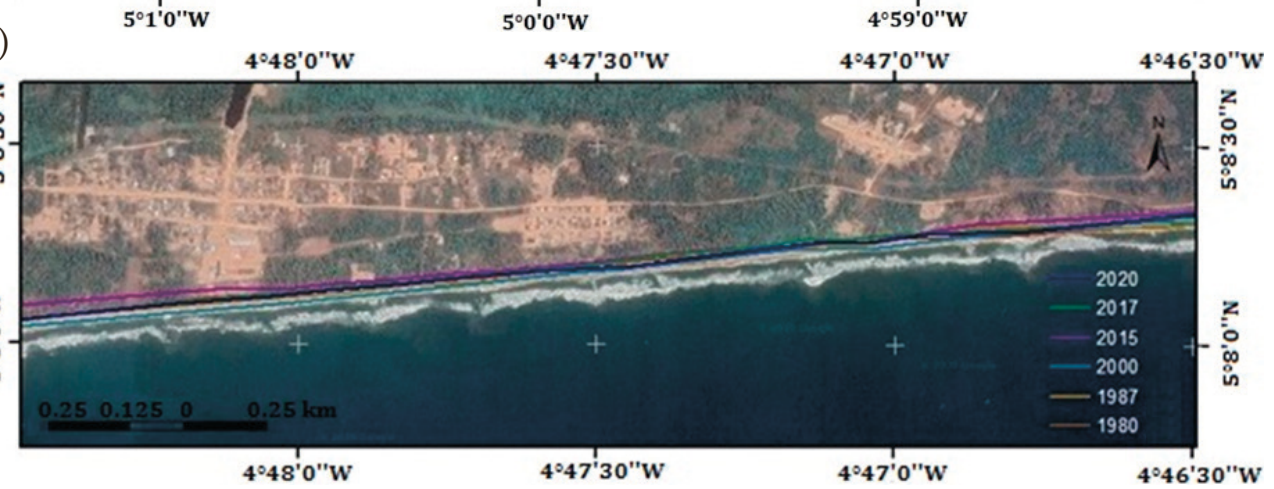

Fig. 4. Coastline kinematics from 1980 to 2020 
Part B is that which characterizes the littoral zone at the mouth (Fig. 4b). It is a zone of instability, and quite tumultuous instability at that. It is an area with a dual trend: erosion and accretion. From 1980 to 1987, the western barrier experienced slight erosion while the eastern barrier experienced slight accretion, frequently changing its environment. From 1980 to 2000, the erosion of the western barrier beach increased, while the eastern barrier beach for this period also experienced shoreline erosion. From 1987 to 2015, the erosion of the western barrier beach was very pronounced, with a significant accumulation on the eastern barrier beach. The retreat of the coastline intensified again from 1980 to 2017 on the western barrier, with an accretion identical to the rate of erosion observed on the western barrier. From 1980 to 2020, the different barriers interpenetrate, the position of the channel is very distant between 1980 and 2020.

Part C characterizes the straight zone of the eastern barrier beach. This zone is very irregular and dominated by periods of erosion (1987-2007, 2015-2020). On the other hand, a trend of strong accretion can be seen at the approach to the mouth (Fig. 4c).

Part A of Lahou-Kpanda is characterized by an erosive trend and a progradation trend, despite being dominated by the accretion period. The reference year 1980 is characterized by two periods of accretion (1980-2000, 1980-2020) and three periods of erosion (1980-1987, 1980-2015 and 1980-2016). The average velocities vary between 0.80 and $1.81 \mathrm{~m} / \mathrm{yr}$ for the accretion periods and between -0.91 and -1.7 for the erosion periods, respectively. The periods 1987-2000 and 1987-2020 are the accretion periods for the base year 1987. Its average velocities are 1.68 and $1.04 \mathrm{~m} / \mathrm{yr}$. It is also characterized by erosion periods (1987-2015 and 1987-2017), with average velocities of -1.06 and $-0.73 \mathrm{~m} / \mathrm{yr}$, respectively. Two periods of erosion and one period of accretion characterize the reference year 2000. They are: 2000-2015 and 2000-2017 for the erosive periods and 2000-2020 as the accretion year. The average velocities are $-4.00,-2.65$ and $0.94 \mathrm{~m} / \mathrm{yr}$, respectively. The base year, 2015, is exclusively accretionary periods with average velocities of 9.17 and $14.70 \mathrm{~m} / \mathrm{yr}$. The 2017-2020 period is an accretionary period with an average velocity of $20 \mathrm{~m} / \mathrm{yr}$.

\subsection{Interpretation of the Sensitivity of the Coastline at Lahou-Kpanda}

The analysis of the dynamics of the Lahou-Kpanda shoreline was done in three (3) sequences: the western straight bar (Fig. 5a), the eastern straight bar (Fig. 5c) and the dynamics at the mouth (Fig. 5b).

The western right barrier (Fig. 5a) is essentially characterized by a significant accretion zone. Average velocities reach $2.5 \mathrm{~m} / \mathrm{yr}$ and accumulation distances can evolve up to $100 \mathrm{~m}$. Groguida is the only locality in this section. Its coastline in particular evolves at an average speed of $1 \mathrm{~m} / \mathrm{yr}$, with an accretion distance reaching about $50 \mathrm{~m} / \mathrm{yr}$. 
The eastern barrier of the coastline is an alternation of erosive and accretionary zones. Thus, the sandy accumulation of the entire eastern shoreline (from the mouth to the eastern straight zone) is estimated at $363,066.07 \mathrm{~m}^{2}$ or 36.29 ha (Fig. $5 \mathrm{c}$ )

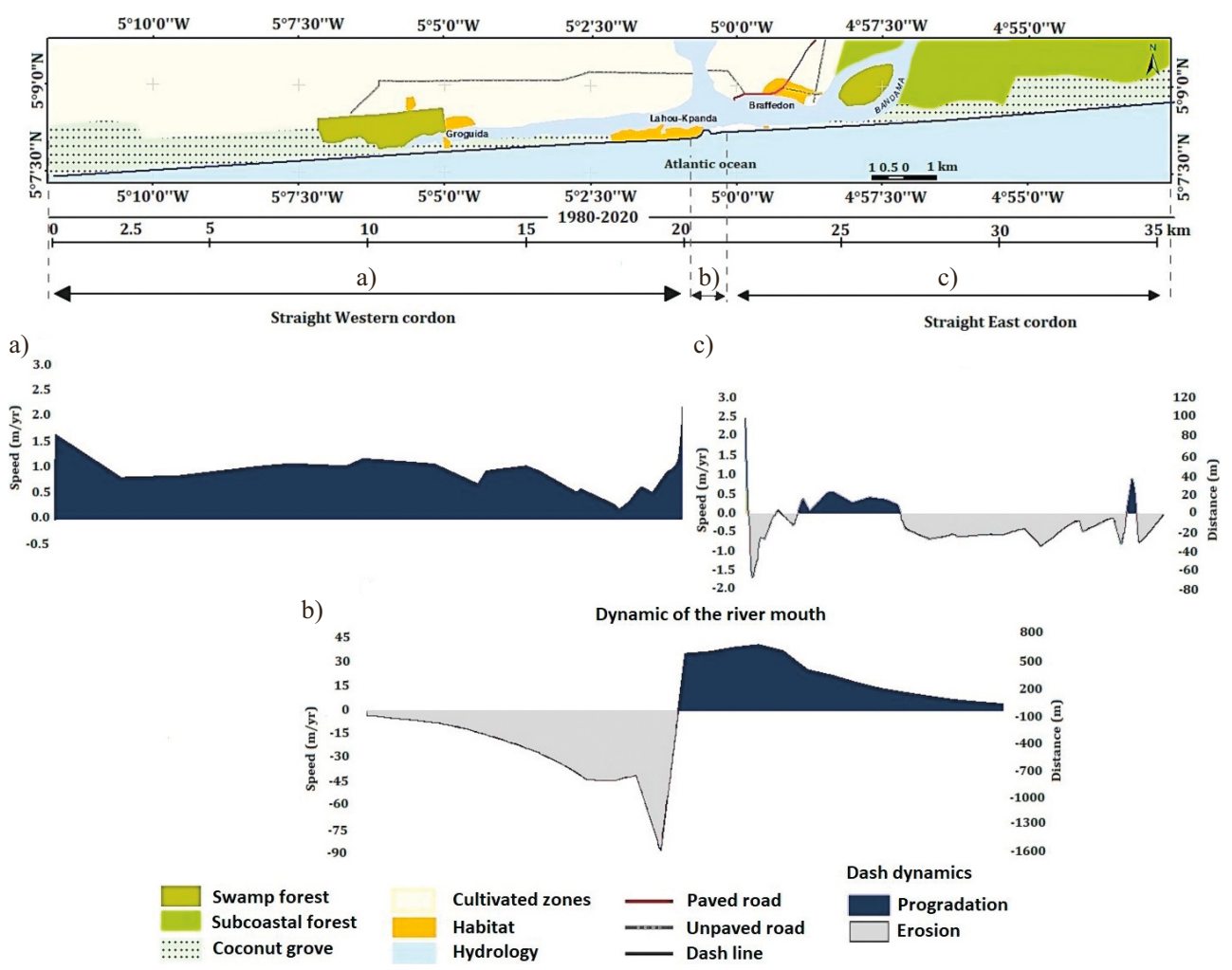

Fig. 5. Coastal segment development from Adiadon to Noumouzou

The mouth section is a very dynamic area, subject to strong erosion on its western side and strong accretion on the east. The average speeds are exorbitant considering the acceleration of the phenomenon on this part of the coastline. The average erosion speed reaches $90 \mathrm{~m} / \mathrm{yr}$, with an average distance reduced by about $2 \mathrm{~km}$. The accretion zone, on the other hand, is of the order of $30 \mathrm{~m} / \mathrm{yr}$ with a maximum distance of about $800 \mathrm{~m}$. The locality of Lahou-Kpanda straddles these two pressures. This situation makes its barrier beach very vulnerable, as it is eroding at an unprecedented rate in all the areas studied (Figs. 4, 5).

\subsection{Surface Analysis of the Coastline of Lahou-Kpanda}

The cordon is made up of a first zone of significant accretion (Fig. 6a). This strong accumulation of earth is estimated at $656,541.46 \mathrm{~m}^{2}$ or 65.65 ha. Part on Figure $6 \mathrm{~b}$ is an alternation of erosive and accretionary zones. The total area under erosion is 
estimated at $538,465.74 \mathrm{~m}^{2}$ or $53.84 \mathrm{ha}$, and the area under progradation is equivalent to $329,277.07 \mathrm{~m}^{2}$ or 32.92 ha. The eastern coast cordon is also an alternation of erosive and accretionary zones (Fig. 6c). The area under erosion is estimated at $129,707.13 \mathrm{~m}^{2}$ or $12.97 \mathrm{ha}$, and the area under progradation is $33,789.07 \mathrm{~m}^{2}$ or $3.37 \mathrm{ha}$. The total surface dynamics for this perimeter is estimated at 168.77 ha.

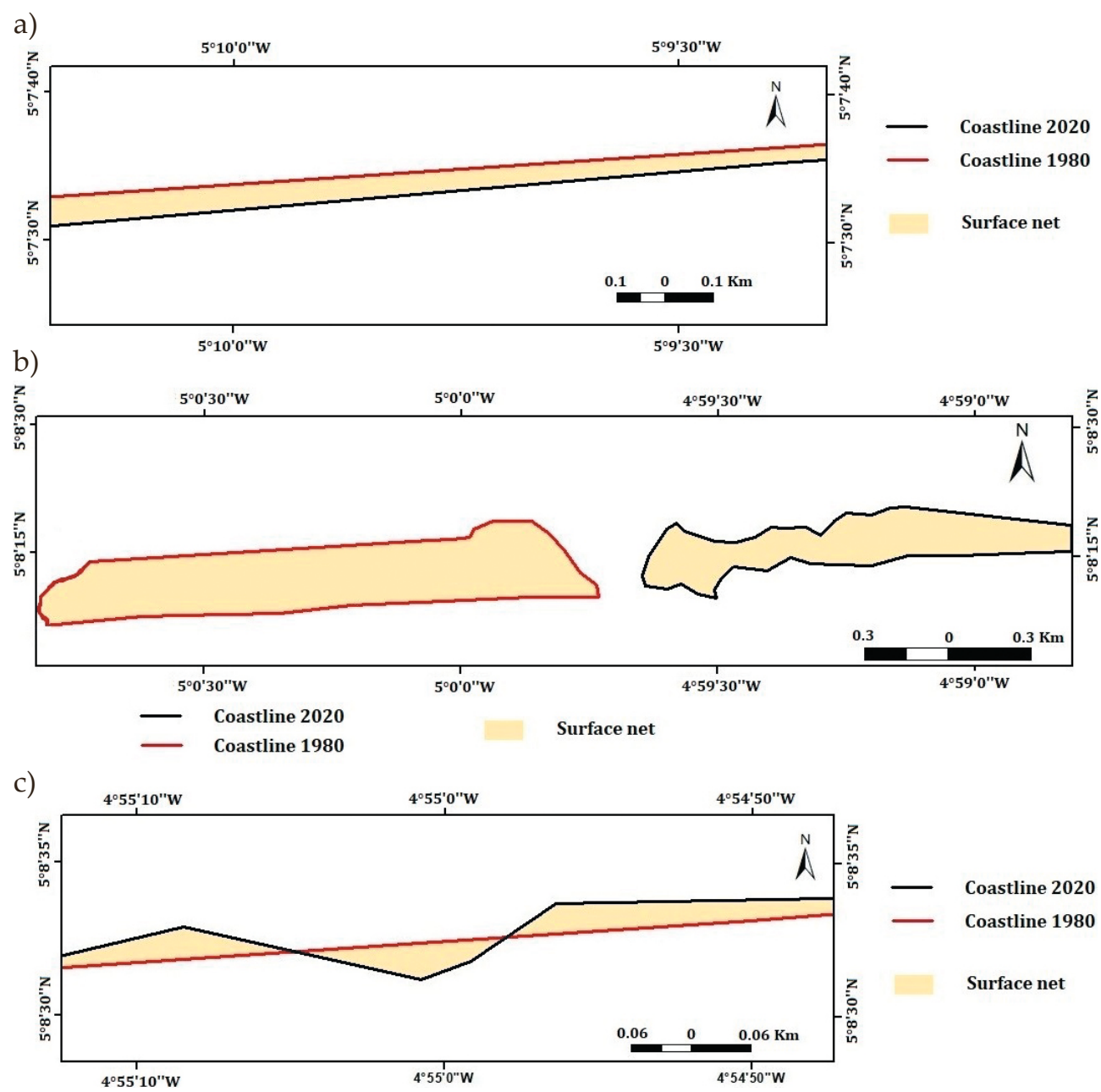

Fig. 6. Surface area assessment of Lahou-Kpanda

\section{Conclusion}

Landsat Data series images (TM, ETM+ and OLI) during the elapsed period from 1980 to 2020 were used to delineate and classify the shorelines along the coast of Lahou-Kpanda (southern Ivory Coast) using the Digital Shoreline Analysis System, 
an excellent approach for coastal zone planning, monitoring, and sustainable development in fast economically growing countries. According to our findings, major changes in the shoreline have occurred over the last 40 years. The share of natural shorelines has moved from a majority to a minority over time, with over $40 \%$ of the biological shoreline lost, showing dramatic changes in areas that comprised the richest areas of biodiversity in the Ivory Coast's littoral zones. The conversion of lowcost shorelines to higher-cost shorelines has shown a clear trend. Economic-oriented human behaviors are the primary driving force behind these shoreline changes. The human activity affecting the coastline is quite unique, and the implications of these developments will be far-reaching, particularly as more and more people are drawn to the coastline, underscoring the necessity to develop and execute suitable adaptive strategies. Rising human activity and growth along the coasts makes marine habitats more vulnerable, as well as the depletion of coastal infrastructure and natural resources due to sea-level rise and storm waves.

\section{Author Contribution}

Badjo Ruth Virginia Zonkouan conducted the image preprocessing, the methodology of the work and analyze the data. Imane Bachri provided important suggestion and reviews for improving the paper. Badjo Ruth Virginia Zonkouan and Imane Bachri wrote the manuscript. Abaze Henri Jöel Beda and Kpangba Aristide Meniansou N'Guessan provided suggestions for improving the paper. All authors approved the final version of the manuscript and agree to be held accountable for the content therein.

\section{References}

[1] Guerrera F., Martín-Martín M., Tramontana M., Nimon B., Kpémoua K.E.: Shoreline Changes and Coastal Erosion: The Case Study of the Coast of Togo (Bight of Benin, West Africa Margin). Geosciences, vol. 11, 2021, 40. https://doi.org/ 10.3390/geosciences11020040.

[2] Passeri D.L., Hagen S.C., Bilskie M.V., Medeiros S.C.: On the significance of incorporating shoreline changes for evaluating coastal hydrodynamics under sea level rise scenarios. Natural Hazards, vol. 75, 2015, pp. 1599-1617. https://doi.org/ 10.1007/s11069-014-1386-y.

[3] Tian H., Xu K., Goes J.I., Liu Q., do Rosário Gomes H., Yang M.: Shoreline Changes Along the Coast of Mainland China - Time to Pause and Reflect? ISPRS International Journal of Geo-Information, vol. 9, 2020, 572. https://doi. org/10.3390/ijgi9100572.

[4] Bevacqua E., Vousdoukas M.I., Zappa G., Hodges K., Shepherd T.G., Maraun D., Mentaschi L., Feyen L.: More meteorological events that drive compound coastal flooding are projected under climate change. Communications Earth \& Environment, vol. 1, 2020, 47. https://doi.org/10.1038/s43247-020-00044-z. 
[5] Thoai T.Q., Rañola R.F., Camacho L.D., Simelton E.: Determinants of farmers' adaptation to climate change in agricultural production in the central region of Vietnam. Land Use Policy, vol. 70, 2018, pp. 224-231. https://doi.org/10.1016/ j.landusepol.2017.10.023.

[6] Aouiche I., Daoudi L., Anthony E.J., Sedrati M., Ziane E., Harti A., Dussouillez P.: Anthropogenic effects on shoreface and shoreline changes: Input from a multi-method analysis, Agadir Bay, Morocco. Geomorphology, vol. 254, 2016, pp. 16-31. https://doi.org/10.1016/j.geomorph.2015.11.013.

[7] Melet A., Teatini P., Le Cozannet G., Jamet C., Conversi A., Benveniste J., Almar R.: Earth Observations for Monitoring Marine Coastal Hazards and Their Drivers. Surveys in Geophysics, vol. 41, 2020, pp. 1489-1534. https://doi.org/ 10.1007/s10712-020-09594-5.

[8] Ghosh M.K., Kumar L., Roy C.: Monitoring the coastline change of Hatiya Island in Bangladesh using remote sensing techniques. ISPRS Journal of Photogrammetry and Remote Sensing, vol. 101, 2015, pp. 137-144. https://doi.org/10.1016/ j.isprsjprs.2014.12.009.

[9] Rasuly A., Naghdifar R., Rasoli M.: Monitoring of Caspian Sea coastline changes using object-oriented techniques. Procedia Environmental Sciences, vol. 2, 2010, pp. 416-426. https://doi.org/10.1016/j.proenv.2010.10.046.

[10] Hauhouot A.C.: Analyse et cartographie de la dynamique du littoral et des risques 'naturels' côtiers en Côte d'Ivoire. Université de Nantes, Nantes 2000 [Ph.D. thesis].

[11] Dominici D., Zollini S.: Remote sensing in coastline detection. Journal of Marine Science and Engineering, vol. 8, 2020, pp. 8-9. https://doi.org/10.3390/ JMSE8070498.

[12] Umar Z., Akib W.A.A.W.M., Ahmad A.: Monitoring shoreline change using remote sensing and GIS: A case study of Padang coastal area, Indonesia. [in:] 2013 IEEE 9th International Colloquium on Signal Processing and its Applications, CSPA 2013, IEEE, 2013, pp. 280-284. https://doi.org/10.1109/CSPA.2013.6530056.

[13] Yasir M., Sheng H., Fan H., Nazir S., Niang A.J., Salauddin M., Khan S.: Automatic Coastline Extraction and Changes Analysis Using Remote Sensing and GIS Technology. IEEE Access, vol. 8, 2020, pp. 180156-180170. https://doi.org/ 10.1109/ACCESS.2020.3027881.

[14] Elkafrawy S.B., Basheer M.A., Mohamed H.M., Naguib D.M.: Applications of remote sensing and GIS techniques to evaluate the effectiveness of coastal structures along Burullus headland-Eastern Nile Delta, Egypt. Egypt. Journal of Remote Sensing \& Space Sciences, vol. 24, 2020, pp. 247-254. https://doi.org/10.1016/ j.ejrs.2020.01.002.

[15] Rangel-Buitrago N., Neal W.J., de Jonge V.N.: Risk assessment as tool for coastal erosion management. Ocean \& Coastal Management, vol. 186, 2020, 105099. https://doi.org/10.1016/j.ocecoaman.2020.105099. 
[16] Orombelli G., Pranzini E.: Considerations on coastal protection and management. Rendiconti Lincei. Scienze Fisiche e Naturali, vol. 31, 2020, pp. 365-368. https://doi.org/10.1007/s12210-020-00912-y.

[17] Assalé P.: Caractérisation sédimentologique, palynologique, géochimique et paléoenvironnementale des formations sédimentaires connexes à la faille des lagunes (Est du bassin onshore de Côte d'Ivoire). Université Félix Houphouët-Boigny (Abidjan, Côte d'Ivoire), Français, 2013 [thesis].

[18] Tagini B.: Esquisse structurale de la Côte d'Ivoire: essai de géotectonique régionale. Bulletin de la Direction des mines et de la geologie de Cote d'Ivoire, 5, SODEMI, 1972.

[19] Tastet J.-P., Martin L., Aka K.: Géologie et environnements sédimentaires de la marge continentale de Côte d'Ivoire. [in:] Le Loeuff P., Marchal E., Amon Kothias J.B. (éd.), Environnement et ressources aquatiques de Côte d'Ivoire. Tome 1: Le milieu marin, ORSTOM, Paris 1993, pp. 23-62.

[20] Douzo J.W.D., Amalaman K.T.S., Dibo W.B., Yao N.J.P., Djeya K.L., Koffi C.L., Digbehi Z.B., Toufiq A., Goha R.B.: Caracterisation Lithostratigraphique et Sedimentologique des Depôts des Sondages de Fresco et de Grand-Lahou (SudOuest de la Côte d'Ivoire): Essai de Correlation et Paleoenvironnements. European Scientific Journal ESJ, vol. 15, no. 15, 2019. https://doi.org/10.19044/esj.2019. v15n15p401.

[21] Digbehi Z., Bi K., Adopo K., Guédé K., Tahi I., Yao K.: Palynologie et environnements de dépôt des sédiments d'âge cénomanien supérieur-maastrichtien inférieur dans le bassin offshore de Côte d'Ivoire (Afrique de l'ouest). Sciences \& Nature, vol. 8, 2011, pp. 95-105.

[22] Tea-Yassi J., Digbehi Z.B., Yao K.R., Glohi B.V.: Étude de quelques palynomorphes du crétace supérieur du bassin offshore de Côte d'Ivoire: implications biostratigraphiques et paléoenvironnementales. Journal of African Earth Sciences, vol. 29, 1999, pp. 783-798. https://doi.org/10.1016/S0899-5362(99)00129-3.

[23] Hinschberger F., Pomel R.: Oro-hydrographie. [in:] Atlas de Côte d'Ivoire, Ministère du Plan de Côte d'Ivoire, ORSTOM, Université d'Abidjan, 1979.

[24] Liu Y., Wang X., Ling F., Xu S., Wang C.: Analysis of Coastline Extraction from Landsat-8 OLI Imagery. Water, vol. 9, 2017. https://doi.org/10.3390/w9110816.

[25] Pardo-Pascual J.E., Almonacid-Caballer J., Ruiz L.A., Palomar-Vázquez J.: Automatic extraction of shorelines from Landsat TM and ETM+ multi-temporal images with subpixel precision. Remote Sensing of Environment, vol. 123, 2012, pp. 1-11. https://doi.org/10.1016/j.rse.2012.02.024.

[26] Wicaksono A., Wicaksono P., Khakhim N., Farda N.M., Marfai M.A.: Semi-automatic shoreline extraction using water index transformation on Landsat 8 OLI imagery in Jepara Regency. [in:] Pham T.D., Kanniah K.D., Arai K., Perez G.J.P., Setiawan Y., Prasetyo L.B., Murayama Y. (eds.), Sixth International Symposium on LAPAN-IPB Satellite, vol. 11372, SPIE, 2019, pp. 500-509. 
[27] Nassar K., Mahmod W.E., Fath H., Masria A., Nadaoka K., Negm A.: Shoreline change detection using DSAS technique: Case of North Sinai coast, Egypt. Marine Georesources \& Geotechnology, vol. 37, pp. 81-95. https://doi.org/ 10.1080/1064119X.2018.1448912.

[28] Bheeroo R.A., Chandrasekar N., Kaliraj S., Magesh N.S.: Shoreline change rate and erosion risk assessment along the Trou Aux Biches-Mont Choisy beach on the northwest coast of Mauritius using GIS-DSAS technique. Environmental Earth Sciences, vol. 75, 2016, 444. https://doi.org/10.1007/S12665-016-5311-4.

[29] Sheik M., Chandrasekar: A shoreline change analysis along the coast between Kanyakumari and Tuticorin, India, using digital shoreline analysis system. Geo-spatial Information Science, vol. 14(4), 2011, pp. 282-293. https://doi.org/ 10.1007/S11806-011-0551-7.

[30] Thieler E.R., Himmelstoss E.A., Zichichi J.L., Ergul A.: The Digital Shoreline Analysis System (DSAS) Version 4.0 - An ArcGIS extension for calculating shoreline change. Open-File Report 2008-1278. https://doi.org/10.3133/ OFR20081278. 